\title{
Solving or Not Solving Problems
}

\author{
JENANNE FERGUSON
}

$\mathrm{T}$ he three articles featured in this issue may not appear to be related, but within their varying contexts, I found myself teasing out several chords that resonate throughout them, and one, in particular, struck me as notable. Directly or indirectly, these articles (as well as the report) all address the notion of problem-solving in some shape or form. Whether a historical account of protest as an attempt to solve issues of discontent among fur trade workers in Russian America, approaches to discussing climate change in northeastern Siberia, coping with failing infrastructure and the negotiation of corporate versus state responsibility-or dealing with COVID lockdowns and scholarly knowledge exchange at present-the articles in this issue all explore the confrontation of problems and how they might be solved.

We begin with a rich and detailed account of infrastructural issues in Verhnemarkovo, a remote oil-focused town in the Irkutsk region northwest of Lake Baikal. This article by Gertrude Saxinger, Natalia Krasnoshtanova, and Gertraud Illmeier investigates the notion of responsibility in terms of who is responsible for solving the problems of transport and mobility infrastructure in this settlement and the gap between citizens' ideals and the reality of the situation. As the authors discuss, residents of Verkhnemarkovo often find themselves caught between state promises and those of the oil companies (who attempt to engage in good corporate citizenship), without clear commitments or tangible results from either institution in terms of who will assure their ability to travel within their town as well as between communities. Thus, problems often go unsolved.

As I write this, the Sakha Republic is experiencing what have been considered the worst forest fires in anyone's memory, after years of progressive escalation. Susan Crate's article, which explores cultural framings of climate change among Viliui region Sakha, is thus especially relevant and highly relatable. In comparing observations of environmental changes by rural Sakha in both 2008 and 2018-as well as reports of a lack of change by some respondents-she covers not only the progression of these shifts but also the ways people differently 
relate to the changes. Through investigating Sakha histories as well as cultural norms around words and speech, she identifies some reasons why narratives other than global climate change may take precedence in explaining local observed climate changes, as well as possible reasons for why such changes may sometimes not be widely articulated or discussed. Crate then suggests potential ideas for raising awareness of global climate change discourse in culturally appropriate ways to lead to better problem solving within conditions of ever-increasing urgency.

The next article, "Social Protest in Russian America," by Andrei Grinëv (translated by Richard Bland) also deals with problem-solving, albeit in a slightly more oblique way. Grinëv presents an overview of information regarding how promyshlenniki (contract workers engaged in fur trading) expressed their discontent with working conditions within the Russian American (Alaskan and Northern Californian) context in the mid-1700s to the mid-to-late 1800s. Protests within the Russian Empire proper have seen a fair amount of attention, but it seems much of the data on Russian America has not yet been fully discussed. Grinëv recounts how most methods of protest were more on the passive side of the scale (desertion, complaint, and sometimes economic sabotage), but nevertheless led to strict attempts from the Russian-American company at the turn of the century onward to squash such displays of dissatisfaction, rather than attempting to change any of its oft-exploitative practices. In this case, we see problems go unsolved, which leads us to speculate at least whether other methods might have seen more or less of a positive result for the protesters.

Finally, the report by Marina Maguidovitch and Lena Sidorova recounts several online and in-person conferences held on the theme of cultural industries of the North and related fields; in discussing the events, the authors also present us with some reflections on problem-solving in the age of COVID, noting some successes occurring with creating connections for faculty and students over the lockdowns and quarantines we have all experienced in 2021. Overall, they adapted well to the changing circumstances, which reminds us that there is at least some hope for all of us for satisfying online conferencing and interactions, whatever the next year brings. 